\title{
OPTIMIZATION TIFTON-85 GRASS CUTTING FOR PRODUCTIVITY AND NUTRIENT VALUE
}

\author{
Daniel OTTONI ${ }^{\text {(D) }}$, Alex de Matos TEIXEIRA² (iD) Lúcio Carlos GONÇALVES ${ }^{3}$ iD, \\ Naiara Taís Alves da SILVA ${ }^{4}$ iD , Diego Soares Gonçalves CRUZ ${ }^{5}$ iD, Izabella Hoske Gruppioni CORTÊS4 (D), \\ João Pedro Costa Alves de OLIVEIRA ${ }^{6}$ iD, Diogo Gonzaga JAYME ${ }^{3}$ iD
}

${ }^{1}$ Veterinary School of the Newton Paiva University Center, Belo Horizonte, Minas Gerais, Brazil.

2 Veterinary School of Federal University of Uberlandia, Uberlandia, Minas Gerais, Brazil.

${ }^{3}$ Department of Zootechnics, Federal University of Minas Gerais, Belo Horizonte, Minas Gerais, Brazil.

4 Postgraduate Program in Zootechnics, Federal University of Minas Gerais, Belo Horizonte, Minas Gerais, Brazil.

${ }^{5}$ Tectron Tecnologia e Inovação, Toledo, Paraná, Brazil.

${ }^{6}$ Fortuna Nutrição Animal, Nova Canaã do Norte, Mato Grosso, Brazil.

Corresponding author:

Diogo Gonzaga Jayme

Email: diogogj@gmail.com

How to cite: OTTONI, D., et al. Optimization tifton-85 grass cutting for productivity and nutrient value. Bioscience Journal. 2021,37, e37009. https://doi.org/10.14393/BJ-v37n0a2021-48179

\section{Abstract}

The objective of this work was to determine the impact of cutting Tifton-85 grass at $14,28,42,46,70$, and 80 days of regrowth on its production and nutritional characteristics during the rainy season. The study area of $238 \mathrm{~m} 2$ was divided into four sub-area, with 6 plots of $2 \times 2 \mathrm{~m}$ spaced $1 \mathrm{~m}$ between plots and $2 \mathrm{~m}$ between sub-area. Random block design was used. The statistical analyses were performed following a randomized block design. Results were obtained as means from evaluations conducted in two consecutive years. The neutral detergent fiber (NDF) and acid detergent fiber (ADF) increased as the cutting age increased. However, crude protein, NDF nitrogen, ADF nitrogen and leaves/stem relationship decreased as the cutting age increased. The production of digestible dry matter increased linearly as the cutting age increased. Similarly, grass height, green matter and dry matter production (DMP) increased as the cutting age increased. The different cutting age did not influence the nitrogen A, B1 + B2, and B3 fractions of the grass. However, the $C$ fraction increased as the cutting age increased. Longer intervals between cuts increased the grass productivity per cut, but compromised its nutritional composition and leaves/stem relationship. For Tifton -85, the regrowth age of 28 days allows greater production of dry matter and greater accumulated production of crude protein and digestive dry matter in the rainy season or over time.

Keywords: Cynodon spp. Digestibility. Nutritional Value. Tropical Grass.

\section{Introduction}

The efficiency of herbivore production is directly associated with the utilization of high-quality grass resources. Provision of cropped grass is an alternative often chosen by producers to supply their system demands. Among the many options, Tifton-85 grass (Cynodon spp.) has been widely utilized for hay and haylage production due to its nutritional quality and high productivity.

Grass nutritional quality is mostly determined by the stage of maturity of the plant, but the regrowth interval between grass cutting influences productivity and chemical composition. In Brazil, there are great differences between climatic and soil characteristics and climate and variations in the effects of age regrowth on the performance and nutritional value of tropical grasses can vary under different edaphoclimatic 
conditions. Grasses that have been harvested with a longer interval of regrowth show higher dry matter (DM) productivity, but poorer quality in comparison with grasses harvested with a shorter regrowth period (Van Soest 1994). Oliveira et al. (2014) note that Cynodon spp. grasses have a linear decrease in effective degradability with an increasing regrowth age. Investigations conducted by Mislevy and Martin (1998) have shown that longer grass regrowth intervals increased Tifton-85 productivity at harvesting. However, (Campos et al. 2010) observed that longer grass regrowth decreased Tifton-85 crude protein (CP, \% DM), and increased neutral detergent fiber (NDF) and acid detergent fiber (ADF). These differences are related to characteristics of the plant and the nutritional value, not only by the content of nutrients such as crude protein, but also by the characteristics of these nutrients. Due to the lack of information more studies on nutrient fractionation are needed. Thus, long grass regrowth intervals can negatively affect the performance of dairy and beef systems despite the increase in grass productivity. As high yield is crucial for system sustainability, an optimized time frame for harvesting could allow greater production and nutritional quality of the plant. Therefore, the understanding of good forage management practices is a key for better livestock productivity.

Many authors have studied Tifton-85 production and nutritional parameters. However, the rate at which such changes occur is specie- or cultivar-specific and can be influenced by environmental conditions. The climate varies from one year to another, so for more consistent results, work is needed that considers at least two harvests or two years of evaluation. Therefore, it is important to analyze forage growth in order to define better forage management strategies. The objectives of this study were to evaluate the production and nutritional parameters of Tifton- 85 grass at different regrowth ages during two consecutive rainy seasons in Brazil.

\section{Material and Methods}

The study was conducted on a farm located at Conselheiro Lafaiete, Minas Gerais, Brazil (20.75431 ${ }^{\circ} \mathrm{S}, 43.8174^{\circ} \mathrm{E}$ ), which has been cropping Tifton-85 grass for over five years for hay production. Grass samples were harvested over 84 days during the rainy seasons of 2012/2013 and 2013/2014. Rainfall was $481 \mathrm{~mm}$ during 2012/2013 and $600 \mathrm{~mm}$ during 2013/2014 (Figure 1). According to the classification established by Köppen, the climate conditions of the region are similar to dry winter in subtropical areas with temperatures lower than $18^{\circ} \mathrm{C}$ at $1027 \mathrm{~m}$.

Soil chemical characteristics in depth of $0-20 \mathrm{~cm}$ and $20-40 \mathrm{~cm}$, respectively, were: $\mathrm{pH}=5.6$ and 5.4; phosphorus $($ resin) $=13.0$ and $12.0 \mathrm{mg} \mathrm{dm}-3$; phosphorus (Mehlich) $=14.0$ and $8.0 \mathrm{mg} \mathrm{dm}-3$; potassium = 0.8 and 0.5 mmolc dm-3; calcium $=17.7$ and 12.0 mmolc dm-3; magnesium $=8.7$ and 5.6 mmolc dm-3; aluminum $=0.0$ and 0.0 mmolc dm-3; potential acidity $=19.0$ and 19.0 mmolc dm-3; sum of basis $=27.1$ and 18.0 mmolc dm-3; cation-exchange capacity $(T)=46.1$ and 37.0 mmolc dm-3; saturation for basis $=58.8$ and 48.7\%; potassium $=1.6$ and $1.2 \% \mathrm{~T}$; calcium $=38.4$ and $32.4 \% \mathrm{~T}$; magnesium $=18.9$ and $15.1 \% \mathrm{~T}$; organic matter = 17.1 and $13.6 \mathrm{~g} \mathrm{dm}-3$; organic carbon = 9.9 and $7.9 \mathrm{~g} \mathrm{dm}-3$; sulfur $=5.5$ and $9.9 \mathrm{mg} \mathrm{dm}-3$; boro = 0.16 and $0.14 \mathrm{mg} \mathrm{dm}-3$; cobre $=0.50$ and $0.30 \mathrm{mg} \mathrm{dm}-3$; iron $=19.80$ and $11.20 \mathrm{mg} \mathrm{dm}-3$; manganese $=0.70$ and $0.30 \mathrm{mg} \mathrm{dm}-3$; zinc $=0.70$ and $0.40 \mathrm{mg} \mathrm{dm}-3$; clay $=42.0 \%$; sand $=23.9 \%$; silt $=34.1 \%$. The study area of $238 \mathrm{~m} 2$ was divided into four sub-area, with 6 plots of $2 \times 2 \mathrm{~m}$ spaced $1 \mathrm{~m}$ between plots and $2 \mathrm{~m}$ between sub-area. Grass cutting order on each sub-area was determined randomly, and grass was harvested at 14, $28,42,56,70$, and 84 days of regrowth. In 2012-2013, one sample of grass at each regrowth age was taken, and in 2013-2014, two samples were collected for each regrowth age, spaced over two regrowth cycles of 84 days.

In October of 2012, Tifton-85 grass was cut to within $2 \mathrm{~cm}$ above ground level in order to standardize the whole area. Thereafter, the area was chemically and biologically fertilized with MAP (mono ammonium phosphate), ammonium sulfate, potassium chloride in order to supply $100 \mathrm{~kg}$ of nitrogen per hectare (N/ha), and poultry bedding in the amount of 5 tons per hectare.

In November of 2013, Tifton-85 grass was again cut to within $2 \mathrm{~cm}$ above ground level in order to standardize the whole area. The soil was chemically fertilized with 20-00-20 of N-P-K in order to supply 100 and $50 \mathrm{~kg}$ of nitrogen per hectare (N/ha) in the first and second cycle, respectively.

Heights of grass blades were measured at five different locations in each sub-area. Thereafter, $1 \mathrm{~m} 2$ was mechanically cut to within $2 \mathrm{~cm}$ above ground level in order to obtain an estimate of green matter 
production per hectare (GMP/ha). Dry matter production per hectare (DMP/ha) was calculated after correcting GMP for dry matter content. Production of digestible dry matter per hectare (DDMP/ha) was obtained as a product of DMP according to the in vitro dry matter digestibility (IVDMD).

Leaf/stem relationship was obtained by separating leaves from the stem plus senescent material of sub-samples of $50 \mathrm{~g}$, then dry matter corrected. The rate of forage liquid accumulation ( $\mathrm{kg} \mathrm{DM} / \mathrm{ha} / \mathrm{d}$ ) was calculated as a proportion between of $\mathrm{DMP} /$ ha and the age of regrowth.

Forage samples of grass collected from each sub-area were dried in a forced-air oven at 55으 for 72 $\mathrm{h}$, then ground in a $1 \mathrm{~mm}$ sieve in preparation for chemical analysis. Samples were also dried in a forced-air oven at 105으 for $6 \mathrm{~h}$ to determine dry matter (DM) content. Crude protein concentration (CP) was calculated as $N \times 6.25$ and nitrogen content was calculated using the Kjeldahl method (AOAC 1995). Ether extract was obtained using the Soxhlet method (AOAC 1995); neutral detergent fiber (NDF) and acid detergent fiber (ADF) were obtained according to (Van Soest et al. 1991), adapted by Ankom ${ }^{\circledR}$ (2006); and lignin by acid hydrolysis (Van Soest et al. 1991). Insoluble nitrogen in neutral detergent (INND) and the insoluble nitrogen in acid detergent (INAD) were obtained according to (Van Soest et al. 1991). Protein fractions (NNP, B1 + B2, B3 and C) were obtained according to the methodology developed by (Sniffen et al. 1992) and in vitro dry matter digestibility (IVDMD) was calculated according to Tilley and Terry (1963).

All the statistical analyses were performed following a randomized block design. Results were analyzed using mean values obtained from samples of different cutting ages collected in each cycle. Design variables were plots (blocks) and cutting age $(14,28,42,56,70$, and 84 days). Each treatment sub-area had 4 replicates, totaling 24 sub-areas. For each replicate, it was attributed the mean value of the three cycles that were sampled. The following statistical model was adopted: $Y i j=\mu+T i+\beta j+€ i j$, in which $Y i j$ is the dependent variable, $\mu$ is the general mean, $\mathrm{Ti}$ is the fixed effect of the treatment, $\beta \mathrm{j}$ is the block effect, and $€ \mathrm{ij}$ is the error $\equiv N(0,1)$. Multiple regression analyses were performed for each cutting age. All statistical analyses were performed in SAS (Statistical Analysis System, version 9.1), and significance assessed at $P \leq$ 0.01 .

\section{Results}

As regrowth progressed, the leaves/stem relationship became less pronounced. The pasture canopy height increased progressively until day 42 of regrowth, after which the grass continued to grow, but at a slower rate. Grass height had increased by a factor of 5.7 at 84 days of regrowth compared to the age of 14 days, whereas the GMP/ha had increased by a factor of 5.26. DMP/ha and DDMP/ha increased by a factor of 6 at 84 days of regrowth compared to the age of 14 days (Table 1).

Table 1. Productive parameters of Tifton- 85 grass at $14,28,42,56,70$ and 84 days of regrowth.

\begin{tabular}{|c|c|c|c|c|c|c|c|c|}
\hline \multirow{2}{*}{ Productive Parameters } & \multicolumn{8}{|c|}{ Regrowth age } \\
\hline & 14 & 28 & 42 & 56 & 70 & 84 & Regression Analysis & $\mathrm{R}^{2}$ \\
\hline GMP (t ha-1 cut $^{-1}$ ) & 6.98 & 21.59 & 28.80 & 30.67 & 38.02 & 36.75 & $\begin{array}{c}y=-0.0072 x^{2}+1.1121 x- \\
6.006^{*}\end{array}$ & 97.33 \\
\hline Height $(\mathrm{cm})$ & 9.34 & 25.78 & 40.25 & 39.16 & 51.00 & 53.65 & $\begin{array}{c}y=-0.0072 x^{2}+1.3139 x- \\
6.327^{*}\end{array}$ & 96.35 \\
\hline DMP $\left(\mathrm{t} \mathrm{ha}^{-1} \mathrm{cut}^{-1}\right)$ & 1.86 & 5.60 & 6.28 & 8.78 & 9.29 & 11.15 & $y=1.7161 x+1.1544^{*}$ & 94.63 \\
\hline $\operatorname{DDMP}\left(\mathrm{t} \mathrm{ha}^{-1} \mathrm{cut}^{-1}\right)$ & 1.00 & 3.21 & 3.79 & 5.11 & 5.58 & 6.39 & $\begin{array}{c}y=-0.0006 x^{2}+0.1273 x- \\
0.6436^{*}\end{array}$ & 99.37 \\
\hline Leaves ( $\mathrm{t} \mathrm{ha} \mathrm{C}^{-1} \mathrm{cut}^{-1}$ ) & 1.31 & 3.15 & 3.54 & 3.04 & 2.97 & 2.57 & - & - \\
\hline Stem (t ha-1 cut $^{-1}$ ) & 0.55 & 2.45 & 2.74 & 5.74 & 6.32 & 8.58 & - & - \\
\hline $\begin{array}{l}\text { Leaves/stem } \\
\text { relationship }\end{array}$ & 2.38 & 1.29 & 1.29 & 0.53 & 0.47 & 0.3 & $y=-0.0274 x+2.3966^{*}$ & 86.69 \\
\hline $\begin{array}{l}\text { Cumulative rate } \\
\left(\mathrm{kgDM}_{\mathrm{ha}}^{-1} \mathrm{~d}^{-1}\right)\end{array}$ & 132.6 & 200.0 & 149.4 & 156.8 & 132.6 & 132.8 & $y=-0.3957 x+170.14$ & 15.57 \\
\hline
\end{tabular}

*P < 0.01; GMP: Green matter production; DMP: Dry matter production; DDMP: Digestible dry matter production.

Increased regrowth age resulted in a change in chemical composition (Table 2). From 14 to 84 days, NDF and ADF increased $18 \%$ and 30\%, respectively, and INND and INAD were reduced by factors of 2.42 and 
2.06, respectively. For each additional day of regrowth age, CP was reduced by $0.8 \mathrm{~kg} / \mathrm{d}$ whereas EE and ash was reduced by $0.4 \mathrm{~kg} / \mathrm{d}$ and $0.6 \mathrm{~kg} / \mathrm{d}$, respectively.

Table 2. Chemical composition of Tifton- 85 grass at $14,28,42,56,70$ and 84 days of regrowth.

\begin{tabular}{lcccccccc}
\hline \multirow{2}{*}{ Chemical Composition } & \multicolumn{7}{c}{ Regrowth age } \\
\cline { 2 - 8 } & 14 & 28 & 42 & 56 & 70 & 84 & Regression Analysis & - \\
\hline DM (\%) & 26.6 & 25.95 & 21.8 & 28.63 & 24.43 & 30.36 & $R^{2}$ \\
ASH (\%DM) & 10.57 & 8.76 & 7.58 & 6.49 & 6.62 & 6.26 & $y=-0.0593 x+10.619^{*}$ & 85.74 \\
EE (\%DM) & 2.51 & 2.64 & 2.57 & 1.98 & 1.77 & 2.01 & $y=-0.0116 x+2.8167^{*}$ & 67.66 \\
NDF (\%DM) & 67.95 & 74.01 & 75.27 & 77.71 & 79.25 & 80.71 & $y=0,1673 x+67,621$ & 91.60 \\
ADF (\%DM) & 33.10 & 36.09 & 37.55 & 40.46 & 41.02 & 43.31 & $y=0.1403 x+31.713^{*}$ & 97.64 \\
Lignin (\%DM) & 7.68 & 7.15 & 6.77 & 6.34 & 7.77 & 8.13 & $y=0.0011 x^{2}-0.0969 x+8.887^{*}$ & 79.88 \\
IVDMD (\%DM) & 0.539 & 0.572 & 0.602 & 0.581 & 0.601 & 0.572 & - & - \\
CP (\%DM) & 15.61 & 12.60 & 11.43 & 7.70 & 8.25 & 7.30 & $y=0.0016 x^{2}-0.2724 x+19.178^{*}$ & 95.58 \\
INAD (\%DM) & 2.37 & 1.64 & 1.40 & 1.05 & 1.09 & 1.15 & $y=-0.0165 x+2.26^{*}$ & 74.12 \\
INND (\%DM) & 7.01 & 5.78 & 4.87 & 3.34 & 3.62 & 2.89 & $y=-0.0584 x+7.446^{*}$ & 91.75 \\
A fraction (\% CP) & 23.56 & 28.19 & 25.09 & 25.70 & 21.23 & 25.92 & - & - \\
B1 and B2 fractions (\% CP) & 31.02 & 25.80 & 32.29 & 31.19 & 36.89 & 34.40 & - & - \\
B3 fraction (\% CP) & 29.03 & 32.80 & 29.41 & 29.38 & 29.70 & 23.29 & - \\
C fraction (\% CP) & 16.36 & 13.19 & 13.19 & 13.71 & 14.5 & 18.05 & $y=0.0033 x^{2}-0.3019 x+19.67$ & 94.92 \\
\hline
\end{tabular}

*P < 0.01; DM: Dry matter; EE: Ether extract; NDF: Neutral detergent fiber; ADF: Acid detergent fiber; IVDMD: In vitro dry matter digestibility; CP: Crude protein; INND: Insoluble nitrogen in neutral detergent; INAD: Insoluble nitrogen in detergent acid.

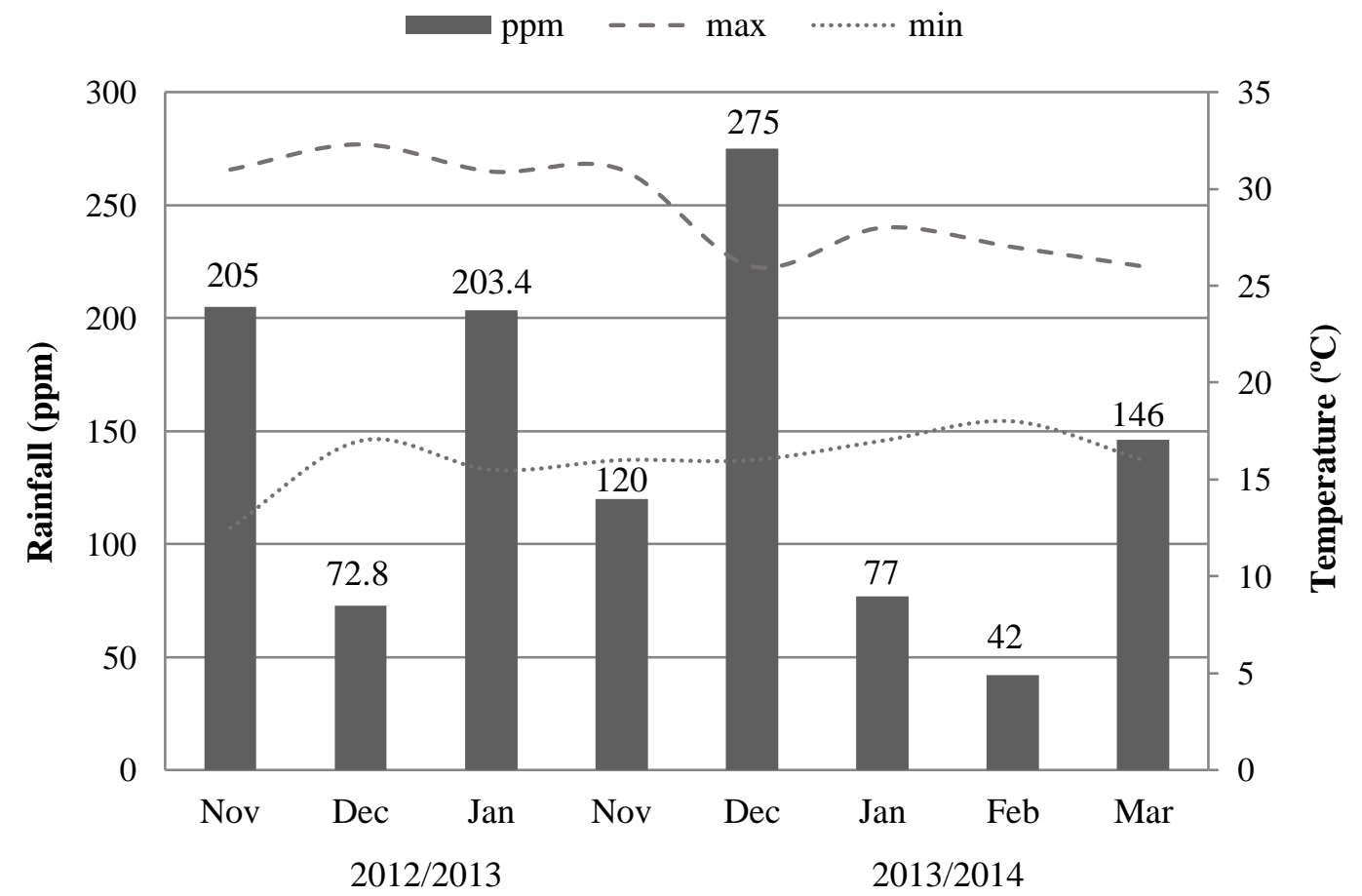

Figure 1. Monthly rainfall (ppm) and average temperature $(\stackrel{\circ}{ }$ ) during the rainy seasons of $2012 / 2013$ and 2013/2014. The average temperature was obtained through a weather station.

\section{Discussion}

The increase in DDMP/ha at 84 days of regrowth compared to that at 14 days could be attributed to a higher GMP/ha, since the IVDMD were not different among ages. The DDMP/ha had a high and positive correlation with GMP/ha $(r=0.93, P<0.01)$, whereas there was no correlation between DDMP/ha and $\operatorname{IVDMD}(r=0.21, \mathrm{P}=0.0669)$.

The DMP/ha had a strong correlation with pasture canopy height $(r=0.84, P<0.01)$. We believe that the maximum growth efficiency of the grass occurred at 42 days of regrowth, after which the grass kept growing at a lower rate. This lower rate could be because of shading of the tiller and the resultant reduction in photosynthesis or a higher proportion of senescent material. Alternatively, it could also be attributed to 
the maturity process of the grass. When the cells of the plant stop growing, the maturation process begins, and secondary wall deposition and lignification limit further growth (Jung 1997). The correlation between pasture canopy height and ADF was higher than that between canopy height and NDF ( $r=0.76 \mathrm{vs.} r=0.69$, $\mathrm{P}<0.01$ ).

Regrowth ages greater than 14 days showed a decrease in the leaves/stem relationship (Alderman et al. 2011). The lower leaves/stem relationship could explain the drop of grasses nutritional value at advanced regrowth ages. The leaves/stem relationship had a negative correlation to ADF $(r=-0.41, P<0.01)$ and NDF $(r=-0.60, P<0.01)$, which could explain the lower nutritional value of grasses as the leaves/stem relationship decreases. The cumulative rate did not differ among regrowth ages. However, CP decreased by half over days 14 and 84 . Thus, an increase in the frequency of cutting can increase the overall CP production without harming the total forage mass. Nevertheless, the best management strategy should take into account the cost of hay processing and the value of the final product.

The reduction in CP content could be related to a lower leaves/stem relationship as the regrowth age increases (Vendramini et al. 2008). Many authors have observed that plants harvested at different regrowth ages present different CP content, with CP decreasing with regrowth age (Corriher et al. 2007; Bow and Muir 2010; Campos et al. 2010; Ribeiro and Pereira 2010; Liu et al. 2011). It could be argued that an increase in grass cutting enhances overall CP production; however, consecutive cuttings in short intervals between cuts can reduce carbohydrate availability, as well as plant vigor (Mislevy and Martin 1998; Liu et al. 2011). Additionally, this practice can harm grass DMP and its sustainability in the system. Therefore, it is important to consider other variables that are involved in the grass production, such as cost of harvesting, cost of concentrate supplementation, rainfall, presence of weeds, and soil fertilization needs when making any management decisions.

Even though the stem can represent a significant portion of the plant after 50 days of regrowth, the proportion of stem at 28 days of regrowth was only $54 \%$ of the proportion observed at 14 days of regrowth.

Harvesting Tifton-85 grass after 27 days of regrowth could reduce system profitability, since it was observed that after this period, the grass can present CP lower than the $13 \%$ minimum value required to classify hay as "premium" (United States Department of Agriculture 2003). The increase in profitability can also happen because during a 180-day rainy season, a regrowth age of 28 days would allow greater accumulated production of CP, DMP/ha and DD

Tifton-85 IVDMD was similar across regrowth ages, possibly because of an increase in new shoots in older plants. Johnson et al. (2002) observed that Bermudagrass harvested at 28-d intervals had a mean IVOMD of 58.0\%. Hill et al. (2013) also observed similar values of Tifton 85 harvested at three ages (3, 5 or 7 weeks). These authors report that Tifton 85 had higher NDF, but with greater digestibility than other grasses Cynodon spp. contrary to most nutritional theories. High NDF values are common for Cynodon spp. grasses, but these high NDF values do not compromise the digestibility of Tifton- 85 due to the low occurrence of concentration of ether-linked ferulic acid (Hill et al. 2013). Ferulates associated with the cell wall of carbohydrates by ether-type binding that are more difficult to break. There was a reduction in INND and INAD as the regrowth age increased. Chiesa et al. (2008) found similar results working with Kikuyo grass at 50 and 90 days of regrowth. Owens et al. (2008) also found similar results in evaluating ryegrass at 28 and 38 days of regrowth. INND and INAD values were expressed as plant dry matter percentage, what explains their reduction with plant maturity. It was also observed that an increase in the $C$ fraction as the plants grow older influences CP quality and digestibility.

There were no differences in CP fractions, other than in C fraction, among regrowth ages. Campos et al. (2010) observed that an increase in the regrowth age resulted in a reduction in the $A$ fraction from $32.34 \%$ at 14 days of regrowth to $22.02 \%$ at 56 days, while the B2 fraction increased from 5.68 to $19.87 \%$ of the CP for the same regrowth ages. Vendramini et al. (2008) studied the interactions between intervals of regrowth (14 and 28 days) and CP A and B fractions of Tifton- 85 grass but did not find any differences. However, they also reported an increase in the $C$ fraction ( $207 \mathrm{vs.} 282 \mathrm{~g} / \mathrm{kg}$ of CP) for the 28-day interval of regrowth. There was a linear increase in lignin content as the regrowth age increased.Thickening of the cell wall by lignin may reduce the digestibility of leaves and stems (Oliveira et al. 2014) and the lignin increase can explain the 10,3 $\%$ increase in fraction $\mathrm{C}$ in this research as the $30 \%$ increase in FDA. 


\section{Conclusions}

Our results indicate that despite the higher productivity of Tifton-85 grass in longer intervals of regrowth, this strategy should be avoided since there is a reduction in the leaves proportion and consequent reduction in the forage nutritional quality. For Tifton -85 , the regrowth age of 28 days allows greater production of dry matter and greater accumulated production of crude protein and digestive dry matter in the rainy season or over time.

Authors' Contributions: OTTONI, D.: acquisition of data, analysis and interpretation of data, drafting the manuscript, final approval; TEIXEIRA, A.M.: conception and design, acquisition of data, analysis and interpretation of data; GONÇALVES, L.C.: conception and design; SILVA, N.T.A.: acquisition of data, final approval; CRUZ, D.S.G.: conception and design, acquisition of data; GRUPPIONI, I.H.: acquisition of data; ALVES, J.P.C.: acquisition of data, drafting the manuscript; JAYME, D.G.: conception and design, acquisition of data, analysis and interpretation of data, drafting the manuscript, final approval.

Conflicts of Interest: The authors declare no conflicts of interest.

Ethics Approval: Not applicable.

Acknowledgments: The authors would like to thank the Largartixa Agrobussiness LTDA for providing the location for this experiment.

\section{References}

ALDERMAN, P., BOOTE, D.K.J. and SOLLENBERGER, L.E. Regrowth dynamics of 'Tifton 85' bermudagrass as affected by nitrogen fertilization. Crop Science. 2011, 51(4), 1716-1726. https://doi.org/10.2135/cropsci2010.09.0515

Association of Official Analytical Chemistry (AOAC). Official Methods of Analysis. 16th ed. Washington: AOAC International, 1995.

BOW, J.R. and MUIR, J.P. Dynamics of harvesting and feeding Cynodon hybrid Tifton 85 hay of varying maturities to wether kids. Small Ruminant Research. 2010, 93(2), 198-201. https://doi.org/10.1016/j.smallrumres.2010.04.023

CAMPOS, P.R.S.S., SILVA, J.F.C. and VÁSQUEZ, H.M. Fractions of carbohydrates and of nitrogenous compounds of tropical grasses at different cutting ages. Revista Brasileira de Zootecnia. 2010, 39(7), 1538-1547. https://doi.org/org/10.1590/S1516-35982010000700021

CHIESA, A.P.R., et al. Age of regrowth as a factor affecting the nutritive value of hay of kikuyu grass (Pennisetum clandestinum) offered to lambs. Grass and Forage Science. 2008, 63(2), 193-201. https://doi.org/org/10.1111/j.1365-2494.2007.00624.x

CORRIHER, V.A., et al. Cow and calf performance on Coastal or Tifton-85 bermudagrass pastures with aeschynomene creep-grazing paddocks. Journal of Animal Science. 2007, 85(10), 2762-2771. https://doi.org/10.2527/jas.2007-0015

HILL, G.M., GATES, R.N. and WEST, J.W. Advances in bermudagrass research involving new cultivars for beef and dairy production. Journal of Animal Science. 2001, 79, 48-58. https://doi.org/org/10.2527/jas2001.79E-SupplE48x

JOHNSON, C.R., et al. Effects of nitrogen fertilization and harvest date on yield, digestibilitym fiiber, and protein fractions of tropical grasses. Journal Animal Science. 2001, 79(9), 2439-2448. https://doi.org/org/10.2527/2001.7992439x

JUNG, H.J.G. Analysis of forage fiber and cell walls in ruminant nutrition. American Society for Nutritional Sciences. 1997, 127(5 Suppl), 810813. https://doi.org/org/10.1093/jn/127.5.810S

LIU, K., et al. Grazing management effects on productivity, nutritive value, and persistence of 'Tifton 85 ' bermudagrass. Crop Science. 2011, 51(1), 353-360. https://doi.org/org/10.2135/cropsci2010.02.0122

MISLEVY, P. and MARTIN F.G. Comparison of Tifton 85 and other Cynodon grasses for production and nutritive value under grazing. Soil Crop Science Society. 1998, 57, 77-82.

OLIVEIRA, R.E., et al. Ruminal degradability of neutral detergent fiber of Cynodon ssp. Grasses at four regrowth ages. Acta Scientiarum Animal Sciences. 2014, 36(2), 201-208. https://doi.org/org/104025/actascianimsdci.v36i2.22469

OWENS, D., BOLAND, T. and MCGEE, M. Effect of grass regrowth interval on intake, rumen digestion and nutrient flow to the omasum in beef cattle. Animal Feed Science and Technology. 2008, 146(1-2), 21-41. https://doi.org/org/10.1016/j.anifeedsci.2007.11.012

RIBEIRO, K.G. and PEREIRA, O.G. Valor nutritivo do capim-tifton 85 sob doses de nitrogênio e idades de rebrotação. Veterinária e Zootecnia. 2010, 17(4), 560-567. https://doi.org/org/10.1590/S1413-70542011000400022

SNIFFEN, C.J., et al. A net carbohydrate and protein system for evaluating cattle diets: II. Carbohydrate and protein availability. Journal of Animal Science. 1992, 70(11), 3562-3577. https://doi.org/org/10.2527/1992.70113562x

TILLEY, J.M.A. and TERRY, R.A.A two-stage technique for the in vitro digestion of forage crops. Grass and Forage Science. 1963, 18(2), 104-111. https://doi.org/10.1111/j.1365-2494.1963.tb00335.x 
VAN SOEST, P.J. Nutritional ecology of the ruminant. $2^{\text {nd }}$ ed. Ithaca: Cornell University, 1994.

VAN SOEST, P.J., ROBERTSON, J.B. and LEWIS, B.A. Methods for dietary fiber, neutral detergent fiber and nonstarch polysaccharides in relation to animal nutrition. Journal of Dairy Science. 1991, 74(10), 3583-3597.

Received: 31 October 2019 | Accepted: 20 May 2020 | Published: 28 January 2021

This is an Open Access article distributed under the terms of the Creative Commons Attribution License, which permits unrestricted use, distribution, and reproduction in any medium, provided the original work is properly cited. 